\title{
In-vitro osteoblast proliferation and in-vivo anti-osteoporotic activity of Bombax ceiba with quantification of Lupeol, gallic acid and $\beta$-sitosterol by HPTLC and HPLC
}

Shashi Chauhan, Aditi Sharma, Navneet Kumar Upadhyay, Gajender Singh, Uma Ranjan Lal and Rohit Goyal' (1)

\begin{abstract}
Background: Bombax ceiba is used traditionally to treat bone disorders, rheumatism, and joint pain. The aim of the study is to carry out osteogenic activity in-vitro and anti-osteoporotic activity in-vivo of stem bark of B. ceiba in surgical ovariectomy model in female rats.

Methods: Plant drug: B. ceiba stem bark was extracted with solvents petroleum ether and methanol using Soxhlet extraction. In-vitro osteoblastic proliferation study was performed using UMR-106 cell lines. Both the extracts were undergone to acute toxicity study as per OECD423 guidelines. Female Wistar albino rats 180-240 g were used $(n=6)$. Surgical ovariectomy was performed under anesthesia to induce bone porosity and loss in all animals except normal control and sham control. Each extract was administered at two dose level: 100 and $200 \mathrm{mg} / \mathrm{kg}$ and the standard Raloxifene was given at $1 \mathrm{mg} / \mathrm{kg}$ orally for 28 days. The phytochemical study of both the extracts was performed using HPLC and HPTLC.

Results: A significant osteoblast cell proliferation and alkaline phosphatase activity were observed with $B$. ceiba extracts in UMR-106 cell lines. Surgical removal of ovaries produced significant $(p<0.05)$ decline in bone mineral density, bone breaking strength, serum ALP, calcium, phosphorus, and estradiol level and marked bone tissue destruction in histology. Administration of petroleum ether and methanolic extract for 28 days significantly $(p<0.05)$ ameliorated the consequences of ovariectomy induced bone porosity and restored the normal architecture of bone, as compared to OVX control. The phytochemical screening of both the extracts were also carried out. The quantification of phytoconstituents showed the presence of $\beta$-sitosterol and lupeol in petroleum ether extract, whereas the lupeol is also quantified in the methanolic extract. The presence of gallic acid was quantified in methanolic extract using HPLC. Conclusion: B. ceiba: stem bark ameliorated the state of bone fragility and fracture possibly due to estrogenic modulation, as also confirmed by in-vitro osteogenic activity which may be due to the presence of lupeol, gallic acid and $\beta$-sitosterol constituents of the plant.
\end{abstract}

Keywords: Bombax ceiba, Lupeol, Gallic acid, Ovariectomy, Osteoporosis, Estrogen

\footnotetext{
* Correspondence: rohitgoyal1505@gmail.com; rohit_pharm@yahoo.co.in School of Pharmaceutical Sciences, Shoolini University, Solan, HP 173212 India
}

(c) The Author(s). 2018 Open Access This article is distributed under the terms of the Creative Commons Attribution 4.0 International License (http://creativecommons.org/licenses/by/4.0/), which permits unrestricted use, distribution, and reproduction in any medium, provided you give appropriate credit to the original author(s) and the source, provide a link to the Creative Commons license, and indicate if changes were made. The Creative Commons Public Domain Dedication waiver (http://creativecommons.org/publicdomain/zero/1.0/) applies to the data made available in this article, unless otherwise stated. 


\section{Background}

Osteoporosis is a progressive, chronic bone disorder of metabolic or hormonal dysregulation and revealed by severe bone porosity, fractures and low bone mass due to microarchitectural deterioration. It occurs due to alteration in the processes of bone tissue formation and resorption, which are characterized by low mechanical bone strength and increased bone fracture [1, 2]. The epidemiology of the debilitating state depicts that approximately 75 million people suffer from bone fragility and other bone disorders in the United States, Europe and Japan [3]. The World Health Organization states that $30 \%$ of postmenopausal women have incidences of bone fractures of the pelvis and lumbar spine or distal forearm [4]. The modern medication suggested to date are calcium and vitamin D supplements, bisphosphonates, selective estrogen receptor modulators, hormone replacement therapy, calcitonin, parathyroid hormone, monoclonal antibodies, and a recombinant form of bone morphogenic protein (BMP)-2 and -6 . But these medications for long-term use cause severe adverse effects like hypercalciuria, hypercalcemia, musculoskeletal pain, osteonecrosis of the jaw, breast tenderness, thromboembolic events, and increased risk of endometrial and breast cancer [5].

Bone remodeling refers to the process of bone formation and sorption of activation of osteoblast and osteoclasts cells respectively. In postmenopausal aged women, the lack of gonadal hormone: estrogen is noted which results in osteoclastogenesis and bone loss. In numerous studies, the state of postmenopausal osteoporosis and estrogen deficiency in women are evaluated by surgical ovariectomy model in female rats. Receptor-activated for Nuclear Kappa (RANK) is expressed in osteoblast progenitors and $\mathrm{T}$ lymphocytes [6-8]. RANK ligand (RANKL) binds to a RANK receptor expressed on osteoclast, causes activation and production of pro-inflammatory mediators: TNF- $\alpha$, IL-1 \& IL-7, and downregulation of osteoprotegerin (OPG) [9]. Physiologically, the expression of fatty acid synthase (FAS) gene is also increased due to a deficiency of estrogen $[10,11]$. FAS is an enzyme capable of de novo long chain fatty acid synthesis [12]. In an in-vitro study, suppression of fatty acid biosynthesis using FAS inhibitor is reported to prevent lipotoxicity in adipocyte on human osteoblasts [13]. In an in-vitro study, co-culture mature adipocytes showed decreased osteoblasts proliferation [14]. The estrogen regulates activation of BMP-2 and transforming growth factor (TGF- $\beta$ ) in osteoblasts [15]. TGF- $\beta$ antagonizes the glucocorticoids induced FAS upregulation [16], and BMP-2 is also reported to suppresses FAS expression [17]. UMR-106 cell has several phenotypic properties matures to osteoblast cells. They appear morphological appearance with calciotropic agents and an expression of alkaline phosphatase as a marker of osteoblastic differentiation, mineralization and bone formation $[18,19]$.

B. cieba L. belongs to the family: Bombacaceae is a deciduous tall tree with typical woody spines on the branches and trunk [20]. Stem bark of the plant is reported to contain lupeol, $\beta$-sitosterol, shamimicin [21], ceibanephthaquinone, silamiln-A and silamalin- $B$ [22], magniferin, epicatechin-3-O-b-xylopyra-noside, epicatechin-7-O-b-xylopyranosid [23], shamiminol, stigmasta-3,5-diene, lupenone and opuntiol [24]. The plant is reported as anti-inflammatory, anti-oxidant, anti-obesity, hepatoprotective, hypoglycemic and hypotensive activities [25, 26]. B. ceiba is used for inflammatory diseases such as asthma, diabetes, wounded glandular swelling [27]. Ethnopharmacologically, it is primarily applied to treat dislocated bones, rheumatism and body pain [28]. The quantification of a flavonoid, quercetin was also reported from the leaves of B. ceiba [29]. Dietary form of quercetin inhibits loss of bone integrity cause due to ovariectomy in mice [30] and documented for bone repair properties [31].

The setting of the study is coupled with the efficacy of Lupeol, Gallic acid, and $\beta$-sitosterol possibly in bone remodeling and hence the present work was hypothesized to investigate the pharmacological activity of $B$. ceiba stem bark extract against the altered state of bone remodeling in surgical ovariectomy-induced osteoporosis in female rats and phytochemical evaluation of $B$. ceiba extract by HPTLC and HPLC.

\section{Methods}

\section{Plant drug extraction and qualitative phytochemical} screening

The stem bark of B. ceiba was collected from Sunder Nagar, HP, India and authenticated from National Institute of Science Communication and Information Resources, New Delhi and a specimen was linked to the institutional herbarium (NISCAIR/RHMD/Consult/11-12/1758/58). Plant part was shade dried, powdered coarsely up to sieve mesh size 10 and stored in an airtight container till further use. Plant drug was extracted with Soxhlet extractor using solvents like petroleum ether and methanol in ratio $1: 3 w / v$ for $48 \mathrm{~h}$. The solvent was slowly distilled, the concentrate was dried in-vacuo and kept in air-tight containers, desiccator. The phytochemical screening of prepared petroleum ether and methanolic extract of $B$. ceiba was carried out to investigate the phytoconstituents like steroids, glycosides, flavonoids, tannins, phenolic, terpenoids, proteins/amino acids, lipids/fixed oil and carbohydrates qualitatively [32, 33]. 


\section{Quantification of gallic acid using high-performance liquid chromatography (HPLC)}

Methanolic extract of $B$. ceiba was fractionated with ethyl acetate. Briefly, $500 \mathrm{mg}$ of methanolic extract was suspended in water $(10 \mathrm{ml})$, fractionated with ethyl acetate $(10 \times 3 \mathrm{ml})$. The ethyl acetate was removed in vacuo to obtain $309.15 \mathrm{mg}$ (61.83\% yield) which was reconstituted with methanol and filtered through $0.22 \mu$ nylon syringe filter. $10 \mu \mathrm{l}$ samples were injected into the HPLC system for $50 \mathrm{~min}$. Gallic acid was dissolved in HPLC-grade methanol. The HPLC system of Agilent technologies 1200 series was composed of EZ-chrome system controller, autosampler, LC-binary pump, diode array detector (at $254 \mathrm{~nm}$ ) and Innoval C18 $(4.6 \mathrm{~mm} \times$ $250 \mathrm{~mm}$ ) column. The mobile phase used for Gallic acid was $0.05 \%$ acetic acid in HPLC-grade water (component A) and 80:20 acetonitrile and $0.05 \%$ acetic acid (component B). The mobile phase was filtered through $0.45 \mu \mathrm{m}$ membrane filter paper and sonicated. A gradient method was adopted as $0-10 \mathrm{~min}, 10 \% \mathrm{~B} ; 10-20 \mathrm{~min}, 10-20 \% \mathrm{~B}$; 20-30 min, $20-40 \%$ B; 30-40 min, $40-60 \%$ B; $40-$ $45 \mathrm{~min}, 60-70 \% \mathrm{~B}$; and $45-50 \mathrm{~min}, 70-10 \% \mathrm{~B}$. The flow rate was set at $1.0 \mathrm{ml} / \mathrm{min}$ of the mobile phase.

\section{Quantification of Lupeol and $\beta$-sitosterol using high- performance thin-layer chromatography (HPTLC)}

The quantification of Lupeol in petroleum ether and methanolic extract and $\beta$-sitosterol in petroleum ether extract of $B$. ceiba was performed using CAMAG HPTLC system which consists of an automatic Linomat V sample applicator, a chamber for developing TLC and a CAMAG TLC scanner for densitometric evaluation of chromatograms. CATS 4 software was used for interpretation of results. Petroleum ether extract was suspended in chloroform $(10 \mathrm{mg} / \mathrm{ml})$, the methanolic extract was in methanol $(10 \mathrm{mg} / \mathrm{ml})$, lupeol and $\beta$-sitosterol dissolved in chloroform $(1 \mathrm{mg} / \mathrm{ml})$. Silica gel 60 F254 HPTLC aluminum sheets $[10 \mathrm{X} 10 \mathrm{~cm}$ with $0.2 \mathrm{~mm}$ thickness] from E. Merck, USA was used. Plant extract sample $(05 \mu \mathrm{l})$ in duplicate was applied over TLC plate $08 \mathrm{~mm}$ wide band using a sample applicator at $12 \mathrm{~mm}$. Each standard marker: lupeol and $\beta$-sitosterol in different concentration $(1-8 \mu \mathrm{g} / \mathrm{ml})$ was applied for preparation of a calibration curve. Nitrogen gas was also supplied for drying of bands simultaneous. Band of each sample was developed in mobile phase n-hexane: ethyl acetate 8:2 in TLC developing camber, saturated with the mobile phase. The developed TLC plate was dried, derivatized with anisaldehyde sulphuric acid reagent and heated to $105{ }^{\circ} \mathrm{C}$ for $5 \mathrm{~min}$. Scan the TLC plate densitometrically using TLC scanner 3 with software: WINCATS at $566 \mathrm{~nm}$ and a fingerprint profile photo was documented. The intensity of the sample in the chromatogram with $R_{f}$ value was quantified at $566 \mathrm{~nm}$ $[34,35]$.

In-vitro osteoblastic proliferation using UMR-106 cell lines UMR-106 cells procured from National Centre for Cell Science (NCCS), Pune, India, were cultured in Dulbecco's modified Eagle's medium (DMEM) supplemented with $10 \%$ fetal bovine serum (FBS), penicillin $100 \mathrm{U} / \mathrm{ml}$ and streptomycin $100 \mathrm{mg} / \mathrm{ml}$ at $37{ }^{\circ} \mathrm{C}$ in a humidified atmosphere of $95 \%$ air and $5 \% \mathrm{CO}_{2}$. At $80-90 \%$ confluence, cells were seeded in 96-well, at a density 2000 cells $/ \mathrm{ml}$, and allowed to attach for $24 \mathrm{~h}$. Then the cells were washed using PBS and co-cultured with serum-free medium mixed with different concentrations of each test sample. The cells were then treated with petroleum ether and methanolic extracts of $B$. ceiba with varying concentrations: namely PE5, PE10 \& PE15: petroleum ether extracts 5, 10, $15 \mu \mathrm{g} / \mathrm{ml}$; ME5, ME10 \& ME15: methanolic extracts 5, 10 and $15 \mu \mathrm{g} / \mathrm{ml}$ respectively; E2: estradiol $(5 \mu \mathrm{g} / \mathrm{ml})$ and vehicle for $48 \mathrm{~h}$. 17ß-Estradiol (E2) was used as a positive control. The medium was co-cultured for $48 \mathrm{~h}$ with the sample solutions in a humidified atmosphere of air $95 \%$ and $\mathrm{CO}_{2} 5 \%$, then the medium was removed and added with MTT solution (1 mg MTT/ml PBS) into each well. The sample was incubated for another $4 \mathrm{~h}$ to allow MTT to metabolize to formazan. The supernatant: MTT [3-(4,5-dimethyl-thiazol-2-yl)- 2,5-diphenyl-tetrazolium bromide] was aspirated from the wells and DMSO $(150 \mathrm{ml}$ per well) was added to dissolve the formazan crystals formed. The absorbance was measured at a wavelength of $595 \mathrm{~nm}$ using an enzyme immunoassay plate reader and the percentage of cell proliferation was calculated using the following formula [36, 37].

$$
\begin{aligned}
\% \text { proliferation }= & (\text { OD sample }- \text { OD control }) \\
& / \text { OD control } \times 100
\end{aligned}
$$

\section{Alkaline phosphatase (ALP) activity}

Cultured cells were rinsed with Ringer solution. Cells were lysed, and cellular material was transferred to buffer $250 \mu \mathrm{l}\left(10 \mathrm{mM} \mathrm{pH}\right.$ 7.5Tris $\mathrm{HCl}, 0.5 \mathrm{mM} \mathrm{MgCl}_{2}$ and $0.1 \%$ Triton $\mathrm{X} 100$ ). The cellular material was homogenized using Teflon homogenizer. ALP activity was performed using p-nitrophenyl phosphate $(4.34 \mathrm{mM})$ in buffer (100 mM glycine $\mathrm{pH} 10.3,1 \mathrm{mM} \mathrm{MgCl}_{2}$. The mixture was incubated for $30 \mathrm{~min}$ at $37{ }^{\circ} \mathrm{C}$. The enzymatic reaction was stopped mixing $50 \mu \mathrm{l}$ of $1 \mathrm{M} \mathrm{NaOH}$ and the absorbance was measured at $405 \mathrm{~nm}$ [38].

\section{Acute toxicity study}

The acute toxicity study of petroleum ether and the methanolic extract was carried out in 2000 and 
$5000 \mathrm{mg} / \mathrm{kg}$ in the present study. No adverse or toxic symptoms were observed under behavioral and biochemical assessments for 1st day, 2, 4 and up to 14 days and both the extracts were found to be safe at 2000 and $5000 \mathrm{mg} / \mathrm{kg}$. The methanolic extract of stem bark of $B$. ceiba has previously been reported to be safe orally in acute toxicity study conducted by our research group and found effective against high fat-induced obesity at 100 and $200 \mathrm{mg} / \mathrm{kg}$ in rodents [39]. In the present study, the two dose levels: 100 and $200 \mathrm{mg} / \mathrm{kg}$ p.o. of both the extracts were identified to use in the further pharmacological evaluation.

\section{Procurement of animals and ethical consideration}

Female Wistar albino rats weighing 180-240 g were procured from Animal house facility of Lala Lajpat Rai University of Veterinary Sciences, Hisar, Haryana, India and kept at the animal house establishment of Shoolini University, Solan, HP, India vide Reg. No. 1541/PO/a/11/ CPCSEA. They were maintained at the temperature of $25 \pm 2{ }^{\circ} \mathrm{C}$ and relative humidity of $45 \pm 5 \%$ and provided with water and food ad libitum. The animals were initially acclimatized to experimental laboratory conditions for 7 days before to experimentation. The experimentation was duly approved from the Institutional Animal Ethical Committee vide protocol no. IAEC/SU-PHARM/ 13/017 and conducted in accordance with the guidelines of Committee for the purpose of control and supervision of experiments on animals (CPCSEA), New Delhi, India which is in confirmation with ARRIVE guidelines prescribed for in-vivo experimentation on small animals.

\section{Surgical ovariectomy-induced osteoporosis in female rat} Osteoporosis was induced by a surgical ovariectomy method as described by Gupta et al. [39, 40]. Female Wistar albino rats were employed and divided into eight groups, each comprising six animals $(n=6)$. Sample size in each group was determined by research papers relevant to the study. Animals were divided into different groups viz. group 1: NC served as normal control received vehicle; group 2: Sham served as surgically operated received vehicle; group 3: OVX control surgical ovariectomy treated received vehicle; group 4 \& 5 : PE100 \& PE200 received petroleum ether extracts 100 \& $200 \mathrm{mg} / \mathrm{kg}$ respectively; group 6 \& 7: ME100 \& ME200 received methanolic extract at $100 \& 200 \mathrm{mg} / \mathrm{kg}$ respectively; and group 8: Std: Ralox received Raloxifene $1.0 \mathrm{mg} / \mathrm{kg}[41,42]$. All the drug treatments were suspended in a vehicle ( $1 \%$ tween 80$)$, given per oral using oral gavage cannula after 5-6 days of recovery of surgical procedures for 28 days. Sham stands for 'placebo surgery', has been installed in the present study to compare the effect of surgical procedures/interventions only.
Rats were anesthetized using ketamine: xylazine at $10: 80 \mathrm{mg} / \mathrm{kg}$, i.p. and underwent a surgical removal of ovaries. Briefly, a 1-3 cm long midline dorsal incision was made in the abdomen region. The peritoneal cavity was assessed, and ovaries were located surrounding fat tissue. Blood vessels at the proximal end of fallopian tube were ligated with catgut stitches and ovaries were removed completely to ensure ovariectomy. Then interstitial muscles and skin were sutured, and postoperative care was done. During postoperative care, the animal was housed individually in a cage, an antibiotic powder was applied to wounds to prevent microbial infection and pus formation and the animal can recover for 3-5 days.

On completion of the protocol, blood samples were collected for biochemical estimations, the animals were sacrificed using a recommended method for euthanasia as per CPCSEA guidelines: decapitation and bones were isolated for biomechanical and histological assessments.

\section{Pharmacological assessments Percentage body weight and BMD}

The change in body weight (\%) was assessed weekly. BMD was also assessed using the Archimedes principle. Left femur bone was hydrated in distilled water for $1 \mathrm{~h}$. Bones were weighed, submerged in distilled water, then weighed out of the water. Density was calculated using the following formula:

$$
\mathrm{BMD}=(\mathrm{A} / \mathrm{A}-\mathrm{B}) \times \mathrm{P}
$$

Where A: weight of hydrated bone out of the water, B: weight of hydrated bone submerged in water, P: density of distilled water at a given temperature and A-B is the weight difference which is equivalent to the volume [43].

\section{Estimation of serum ALP, calcium and phosphorus level}

Serum biochemical estimations like alkaline phosphatase (ALP) using the Tris carbonate buffer method, calcium using O-cresophathaleincomplexone (OCPC) method and phosphorus using ammonium molybdate method were done using enzymatic kits from Erba Diagnostic Mannheim, Daman [44].

\section{Estimation of serum estradiol level}

Serum estradiol level was estimated by an electrochemiluminescence analyzer: automatic (Elecsys 1010; Roche Inc., Germany) using kit $(100 \mathrm{~T})$ and by enzyme immunoassay (EIA) using a spectrophotometric apparatus [45]. 


\section{Biomechanical assessments}

\section{Three-point bending of tibia}

A supporter with two loading points, $13 \mathrm{~mm}$ apart from each other was used on the stage of the testing machine. The lateral surface of the tibia at the tibiofibular junction was placed upon the first point and proximal tibia upon the other. A rounded press head compressed the middle of the tibial shaft until a fracture occurred [46].

\section{Compression of the fourth lumbar vertebra}

The fourth lumbar vertebra was located and isolated. The fresh vertebra was placed on the flat metal stage and compressed until it fractured. The reading was recorded in Newtons [47].

\section{Femoral neck loading test}

In femoral neck loading test, the head was loaded with a parallel force to the shaft until fracture. A flat surface metal clamp was used to fix the proximal part of the femur perpendicular and to fix tight. Loading of head was done using a concave compression head (2.5 mm). The amount of force for breaking down head was noted [46].

\section{Histological study of bone tissue}

The femur bones of rats were embedded in 10\% formalin solution. Bones were decalcified in 5\% ethylenediaminetetraacetic acid. The decalcified bones were fixed in paraffin wax and cut into plane thin sections using manual microtome. Hematoxylin and eosin stains were used to examine the histopathological changes under a light microscope at 40X.

\section{Statistical analysis}

Research finding was presented as mean \pm standard deviation (SD) and statistical analysis: one-way analysis of variance (ANOVA) was applied using GraphPad Prism software (version 5) followed by Bonferroni's multiple comparison tests, a post-hoc test. A $p$-value $<0.05$ was statistically significant.

\section{Results}

The extraction of powdered B. ceiba Linn. stem bark resulted in a yield of petroleum ether extract $2.17 \% \mathrm{w} / \mathrm{w}$ and that of methanolic extract $6.37 \% \mathrm{w} / \mathrm{w}$. Qualitative phytochemical screening of prepared extracts was presented in Table 1.

\section{Quantification of Gallic acid in B. ceiba by HPLC}

The HPLC chromatogram of Gallic acid was obtained at a wavelength of $254 \mathrm{~nm}$. The HPLC chromatogram of a methanolic extract of $B$. ceiba extract was compared with the UV spectrum of Gallic acid in the test sample and presented in Fig. 1. A linear progression analysis
Table 1 Qualitative phytochemical screening of plant extracts of $B$. ceiba

\begin{tabular}{llll}
\hline S. No. & Chemical test & Pet. ether extract & Methanolic extract \\
\hline 1. & Alkaloids & - & - \\
2. & Anthraquinone glycosides & - & - \\
3. & Saponin glycosides & - & + \\
4. & Cardiac glycosides & - & - \\
5. & Carbohydrates & - & + \\
6. & Flavonoids & - & + \\
7. & Tannins & - & + \\
8. & Steroids & + & - \\
9. & Triterpenoids & + & + \\
10. & Fats/lipids/fixed oil & + & - \\
11. & Proteins and amino acids & - & -
\end{tabular}

$(+)$ indicate presence and (-) indicate absence

with equation $y=63,432 \times-238,517, R^{2}=0.9910$ was carried out. Gallic acid in the stem bark of $B$. ceiba is being reported for the first time in the present study and was found to be $3.616 \% \mathrm{w} / \mathrm{w}$ in the methanolic extract $(5.84 \% \mathrm{w} / \mathrm{w}$ in ethyl acetate extract of methanolic extract) with retention time $4.527 \mathrm{~min}$.

\section{Quantification of $\beta$-sitosterol and lupeol in B. ceiba by HPTLC}

A calibration curve of $\beta$-sitosterol and lupeol as concentration $(\mu \mathrm{g} / \mathrm{ml})$ vs area under the curve (AU) was plotted using HPTLC. A linear progression analysis for $\beta$-sitosterol with the equation: $y=1286.5 x+6096.6, R^{2}=$ 0.9562; and for lupeol with the equation: $y=1609.4$ $x-2662.4, R^{2}=0.9901$ were done. The percentage yield of $\beta$-sitosterol was $3.806 \% \mathrm{w} / \mathrm{w}$ with $\mathrm{Rf}$ value 0.27 in petroleum ether extract whereas of lupeol was $5.292 \% \mathrm{w} / \mathrm{w}$ in petroleum ether extract and $3.812 \% \mathrm{w} / \mathrm{w}$ with $\mathrm{Rf}$ value 0.67 in methanolic extract of $B$. ceiba. HPTLC chromatograms were presented in Fig. 2a, b, c and d.

\section{Osteoblastic cell proliferation and ALP activity}

The effect of $\boldsymbol{B}$. ceiba extract on osteoblastic cell proliferation was studied by treatment of rat osteoblastic UMR-106 cells at concentrations of $5-20 \mu \mathrm{g} / \mathrm{ml}$ for 48 h. B. ceiba extract increased the optical density of the purple formazan product in the MTT assay. The results showed the greatest increase in cell proliferation at $10 \mu \mathrm{g} / \mathrm{ml}$ by both extracts. Whereas, the effect produced by methanolic extract at 10 and $15 \mu \mathrm{g} / \mathrm{ml}$ was significant to that of PE 15 . Increase in cell viability and mitochondrial activity was estimated using MTT assay and increased osteogenic activity was also noted as detected by the ALP assay. However, the effect of ME15 and PE15 on ALP level UMR cells reflects the cessation of response till ME10 and PE10 concentrations respectively. 


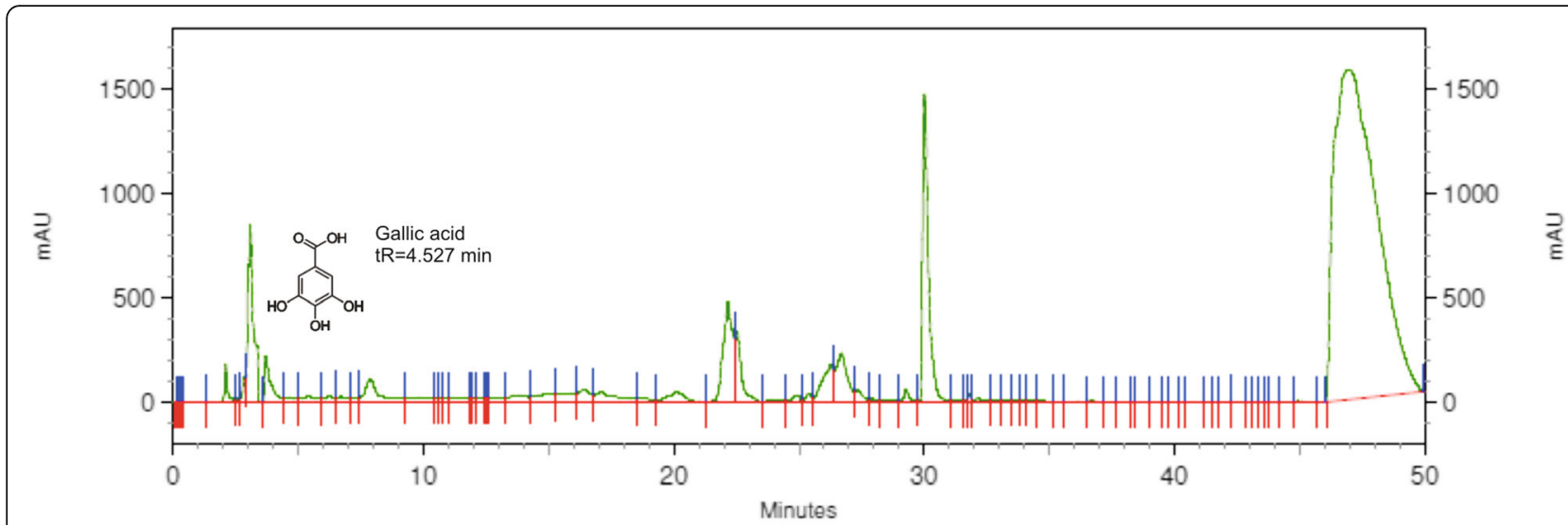

UV spectrum of Gallic acid (standard) and in Bombax ceiba extract
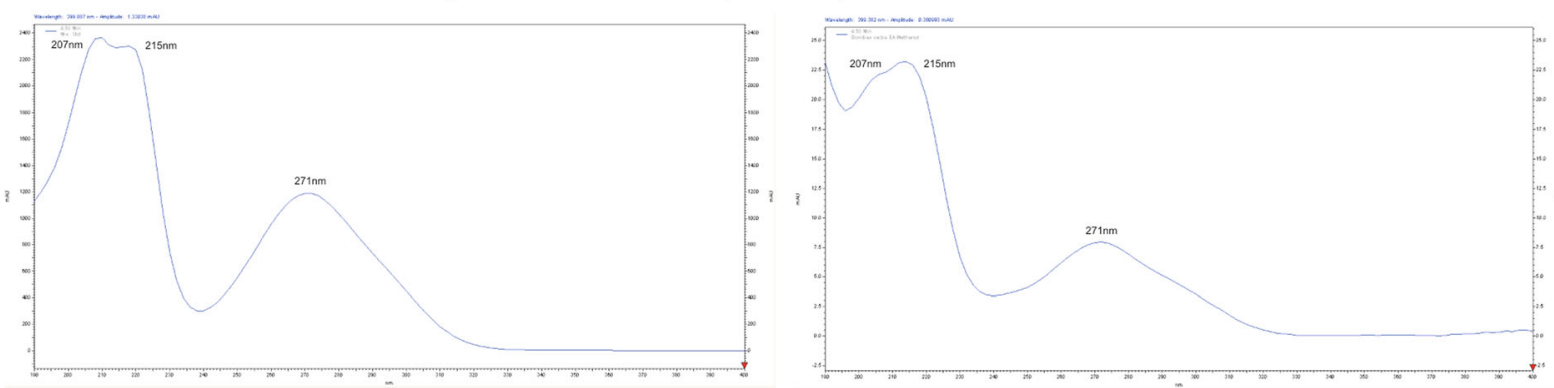

Fig. 1 HPLC chromatogram for the quantification of gallic acid in the methanolic extract of B. ceiba and UV spectrum of Gallic acid at $254 \mathrm{~nm}$

A

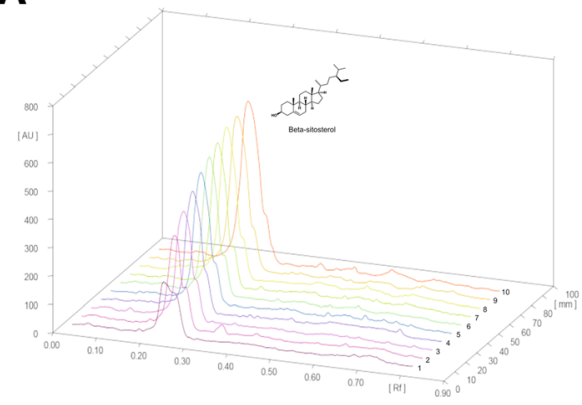

C

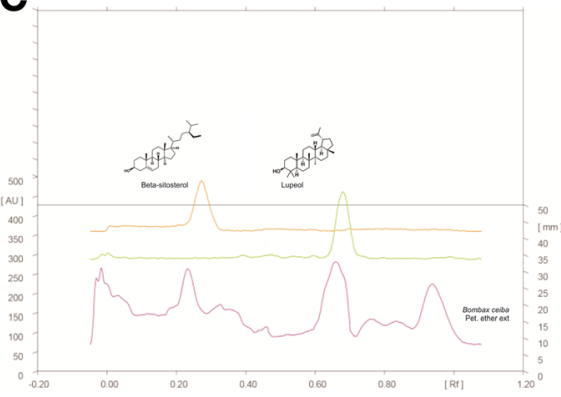

B

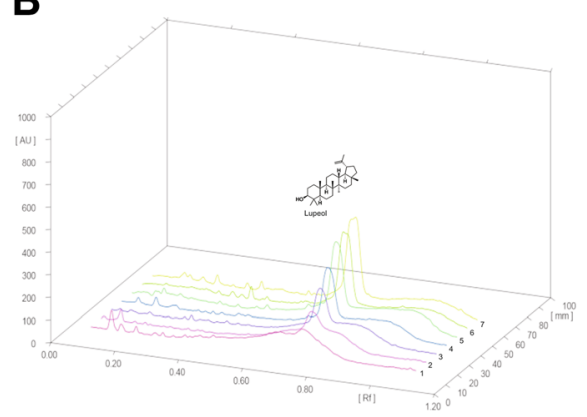

D

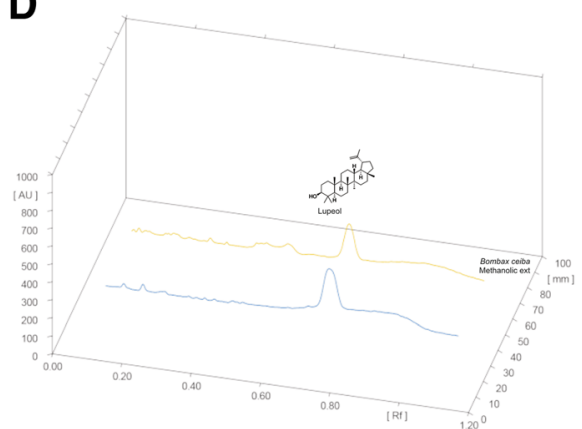

Fig. 2 HPTLC chromatograms: a Calibration curve for $\beta$-sitosterol; b Calibration curve for lupeol; c Quantification for $\beta$-sitosterol and lupeol in petroleum ether extract; and $\mathbf{d}$ Quantification of lupeol in methanolic extract of $B$. ceiba. Results: mean \pm SD, analyzed by one-way ANOVA followed by Bonferroni's multiple comparison tests; ${ }^{*} P<0.05$ vs $C$ (control); ${ }^{\#} P<0.05$ vs $P E 15$ 
The lower concentration of each extract from 0.5 to $5 \mu \mathrm{g} / \mathrm{ml}$ is suggested further for assessment over in-vitro assays (Fig. 3a and b).

\section{Effect of $B$. ceiba on the percentage change in body weight}

Surgical ovariectomy produced a significant increase in percentage change in body weight in OVX group, as compared to sham control. Petroleum ether and methanolic extracts at 100 and $200 \mathrm{mg} / \mathrm{kg}$ each of B. ceiba produced significantly $(p<0.05)$ decrease in percentage change in body weight as compared to OVX group. The effect of high dose $(200 \mathrm{mg} / \mathrm{kg})$ of methanolic extract was found to be insignificant $(p>0.05)$ to that of standard Raloxifene (Fig. 4a).

\section{Effect of B. ceiba on BMD}

Surgical removal of ovaries caused a significant decrease in BMD in the OVX group as compared to sham control. Whether treated with a pet. Ether and methanolic extract at 100 and $200 \mathrm{mg} / \mathrm{kg}$ of $B$. ceiba produced significantly $(p<0.05)$ increase in BMD as compared to OVX group. In addition, the highest dose $(200 \mathrm{mg} / \mathrm{kg})$ of both the extracts produced insignificant $(p>0.05)$ increase in BMD to standard Raloxifene (Fig. 4b).

\section{Effect of B. ceiba on serum biochemical parameters}

Surgical removal of both the ovaries produced significant $(p<0.05)$ reduction in serum ALP, calcium and phosphorus levels in the OVX control group, in comparison to sham control. Petroleum ether and methanolic extracts of B. ceiba at 100 and $200 \mathrm{mg} / \mathrm{kg}$ produced significant $(p<0.05)$ increase ovariectomy-induced serum biochemical changes, as compared to the OVX group. The effect produced by highest dose, $200 \mathrm{mg} / \mathrm{kg}$ of methanolic extract was found to be insignificant $(p>$ $0.05)$ when compared with the standard drug: Raloxifene (Fig. 5a, b and c).
Effect of $B$. ceiba on serum estradiol level

Deficiency of estrogen was noted due to surgical ovariectomy in female rats as compared to normal control $(p<0.05)$. Petroleum ether and methanolic extracts of $B$. ceiba were significantly recovered the estrogen level in comparison to OVX control $(p<0.05)$. Plant extract in highest doses could produce an effect equivalent to Raloxifene $(p>0.05)$ (Fig. $5 \mathrm{~d})$.

\section{Effect of B. ceiba on bone biomechanical parameters}

In the OVX group, surgical ovariectomy produced a significant decrease in bone strength of tibia, lumber and femoral vertebra, as compared to sham control. On treatment with petroleum ether and methanolic extract of B. ceiba at 100 and $200 \mathrm{mg} / \mathrm{kg}$ caused significant $(p<0.05)$ increase in bone strength of the bones, when compared to OVX group. The highest dose, $200 \mathrm{mg} / \mathrm{kg}$ of both extracts produced an effect in strengthen insignificant $(p>0.05)$ increase in bone strength of the tibia as compared to standard Raloxifene (Fig. 6a, b and c).

\section{Effect of B. ceiba on bone histopathological characteristics}

The histopathological observations of right femur (proximal diaphysis region) of rats revealed compact, normal and uniform trabecular bone, which was recognized with appropriate interconnectivity between the bone trabeculae and narrow bone marrow spaces or inter-trabecular spaces in normal and sham control groups. OVX control group showed the destruction of the normal architecture of bone in the form of thinning of trabecular bone, loss of interconnectivity between trabeculae and widening of bone marrow spaces. Treatment with petroleum ether extract showed less separated bone trabeculae, interconnectivity between the bone trabeculae and reduced narrowing of bone marrow spaces. Methanolic extract of $B$. ceiba showed significant restoration of normal architecture as adequate interconnectivity between the bone trabeculae, narrowing of bone marrow spaces and
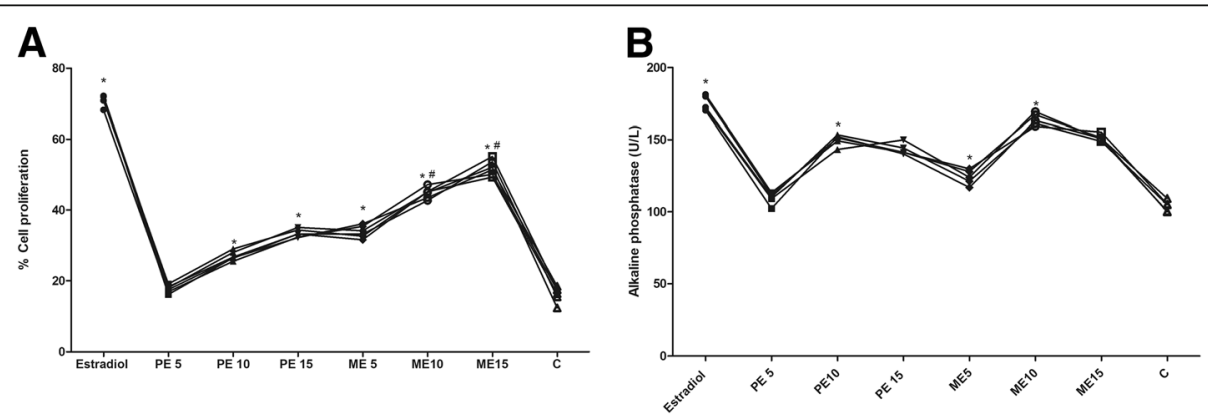

Fig. 3 The effects of B. cieba on osteoblast-like UMR106 lines (a) Cell proliferation (b) ALP activity. Results: mean \pm SD, analyzed by one-way ANOVA followed by Bonferroni's multiple comparison tests; ${ }^{a} p<0.05$ vs. Sham; ${ }^{b} p<0.05$ vs. OVX; ${ }^{c} p>0.05$ vs. Std Ralox 

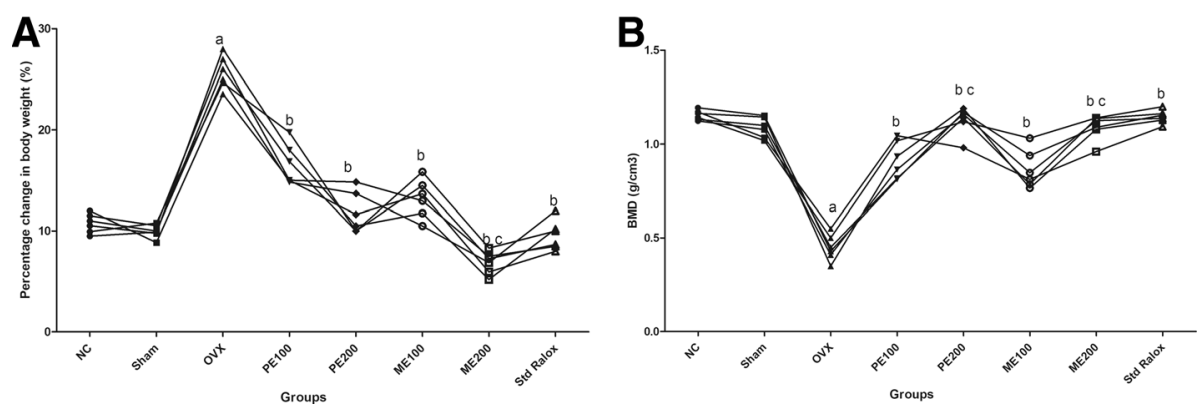

Fig. 4 Effect of plant extracts of B. ceiba on (a) percentage change in body weight; and (b) bone mineral density. Results: mean $\pm S D$, analyzed by one-way ANOVA followed by Bonferroni's multiple comparison tests; ${ }^{a} p<0.05$ vs. Sham; ${ }^{b} p<0.05$ vs. OVX; ${ }^{c} p>0.05$ vs. Std Ralox

thickening of trabecular bone. A significant restoration of bone integrity was also observed during treatment with standard drug Raloxifene (Fig. 7).

\section{Discussion}

The present study evidenced for the anti-osteoporotic effect of the stem bark of $B$. ceiba by providing osteogenic, estrogenic effects and amelioration of bone remodeling in surgically ovariectomy-induced osteoporosis in the female rat. Postmenopausal osteoporosis occurs due to the ovarian deficiency of a hormone, estrogen, which is a most common cause of age-related postmenopausal bone porosity and fragility [48] and is possibly evident caused by a surgical ovariectomy method in female rats [49]. Osteoporosis occurs due to uncoupling between bone formation by osteoblasts and bone resorption by osteoclasts during the bone remodeling process [50]. Estrogen deficiency causes increased bone resorption, microarchitectural deterioration and reduced bone mass [51]. Estrogen is also reported to increase the activity of FAS [10] and FAS activation is reported to decrease the proliferation of osteoblast [14]. The release of an inflammatory mediator like TFG- $\beta$ antagonizes the FAS activity [16]. Postmenopausal women become obese due to the accumulation of fat because estrogen helps in fat breakdown [52].

The results from in vitro study provide additional evidence for the protective effects of $B$. ceiba extract on the bone with enhancement of matrix ossification which was found in rat osteoblast-like UMR-106 cells indicating the existence of osteogenic activity of plant constituents. Plant extracts showed marked efficacy in the

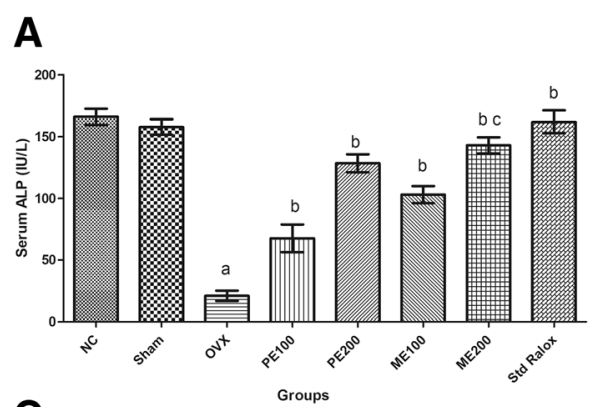

B
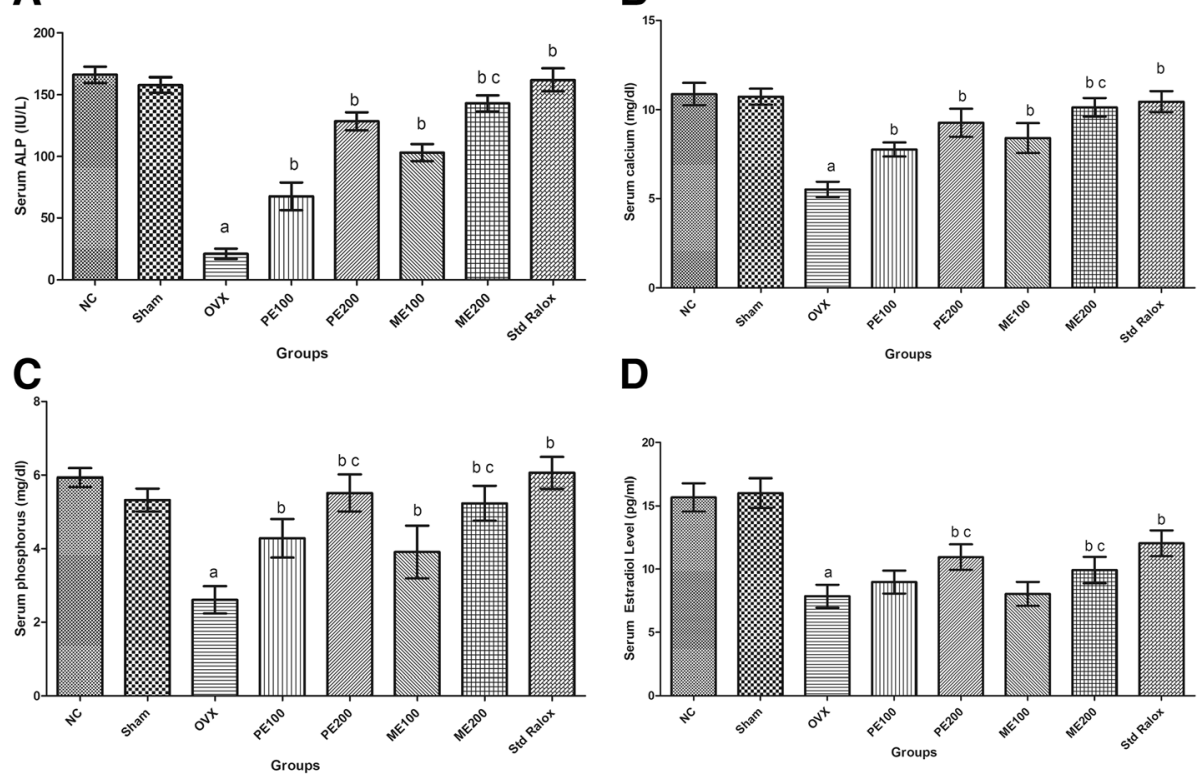

D

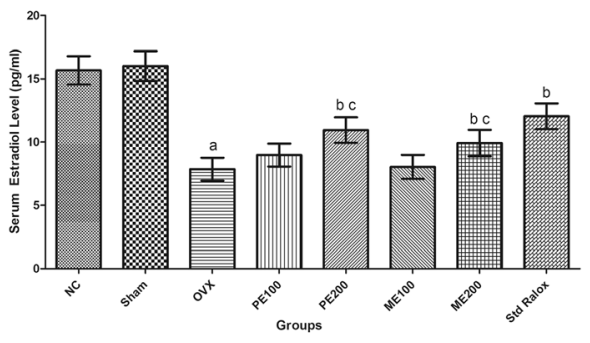

Fig. 5 Effect of plant extracts of B. ceiba on serum biochemical parameters, (a): ALP, (b): calcium, (c): phosphorus, (d): Estradiol levels. Results: mean \pm $\mathrm{SD}$, analyzed by one-way ANOVA followed by Bonferroni's multiple comparison tests; ${ }^{a} p<0.05$ vs. Sham; ${ }^{b} p<0.05$ vs. OVX; ${ }^{c} p>0.05$ vs. Std Ralox 

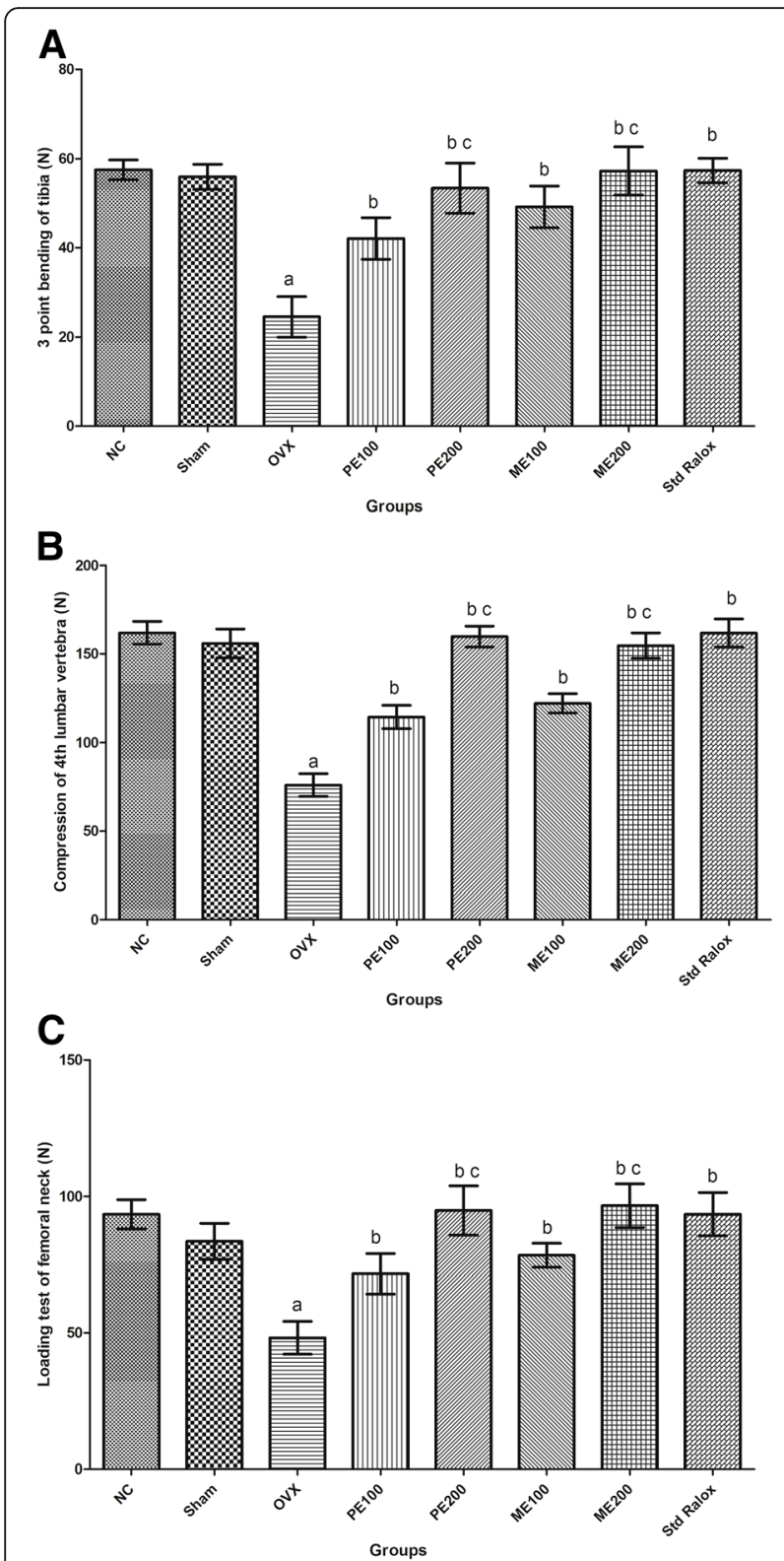

Fig. 6 Effect of plant extracts of B. ceiba on biomechanical parameters; (a) Three-point bending of the tibia, (b) Compression of the 4th lumbar vertebra, (c) Loading test of femoral neck

proliferation of UMR cell lines against MTT. Whereas in ALP expression study, the maximum effect was ceased at $10 \mu \mathrm{g} / \mathrm{ml}$ of each extract and highest concentration showed decreased response which may be due to saturation of target receptor sites.

The surgical ovariectomy in female rodents is a valid method to characterize the symptoms of osteoporosis and used to test the efficacy of new therapeutic agents $[39,40]$. Surgical removal of both the ovaries in female rat causes decrease in estrogen level and the state is also attributed with an increase in body weight, decrease in bone mineral density, deterioration of bone integrity \& architecture, increase in intertrabecular spaces or narrowing of bone marrow spaces as in ovariectomized animals. These changes resemble the clinical cases of increased bone fracture observed in postmenopausal women [53]. Treatment with petroleum ether and methanol extracts 100 and $200 \mathrm{mg} / \mathrm{kg}$ each of the $B$. ceiba and standard drug: Raloxifene $(1 \mathrm{mg} / \mathrm{kg})$ produced a significant decrease in percentage change in body weight and increase in BMD. The effect produced from the highest dose: $200 \mathrm{mg} / \mathrm{kg}$ of methanolic extract was as much as potent as that of standard drug. In the present study, surgical removal of both the ovaries caused a significant decrease in estrogen and its possible reversal is seen in treatment with a petroleum ether and methanolic extracts in high doses to some extent, as compared to OVX control. In women, estrogen is produced primarily from ovaries, corpus luteum, placenta and nongonadal organs such as liver, heart, skin adipose tissue and brain. In the postmenopausal state, the production and release of estrogen from non-gonadal organs appear to be vital for bone remodeling process by B. ceiba and maintains other body functioning.

Alkaline phosphatase is an enzyme found throughout the body and has been considered as a bone-specific marker for mineralization. ALP mainly represents bone metastases in a process of bone remodeling [54]. Ovariectomy results in decreased serum ALP level, which is an indication of bone loss [55]. Treatment with both the extracts $B$. ceiba produced a significant increase in serum ALP level. Calcium (Ca) and phosphate (P) are the two essential micronutrients and constituents of hydroxyapatite, the bone mineral which provides compactness and mechanical resistance to organic matrix. During postmenopausal state, the estrogen deficiency affects the absorption of the micronutrients from GIT and presence in the circulation which is maintained from the reservoir i.e. bone and causes a decline in the serum levels [56]. B. ceiba extract showed an elevated level of calcium which may be due to its effect on $\mathrm{Ca}$ absorption, and its maintenance in bone, activation of osteoanabolic and stimulation of gonadal effects contributing matrix deposition during osteogenesis [57]. In the present study, estrogen deficiency may cause the release of inflammatory mediators which further lead to activation of MHC-II and T cell producing more RANKL and TNF- $\alpha$ which are osteoclastogenic factors [58]. Estrogen deficiency causes an increase in FAS gene expression in the periosteum, negatively regulates the synthesis of TGF- $\beta$ and BMP-2 in osteoblasts $[17,21]$ and results in a lipotoxic effect on osteoblasts. In the study, there was a significant decrease in bone strength of the tibia, femur and lumbar bones of OVX rat was observed. These changes observed in biomechanical assessments: three-point bending of the tibia, compression of the 4th 

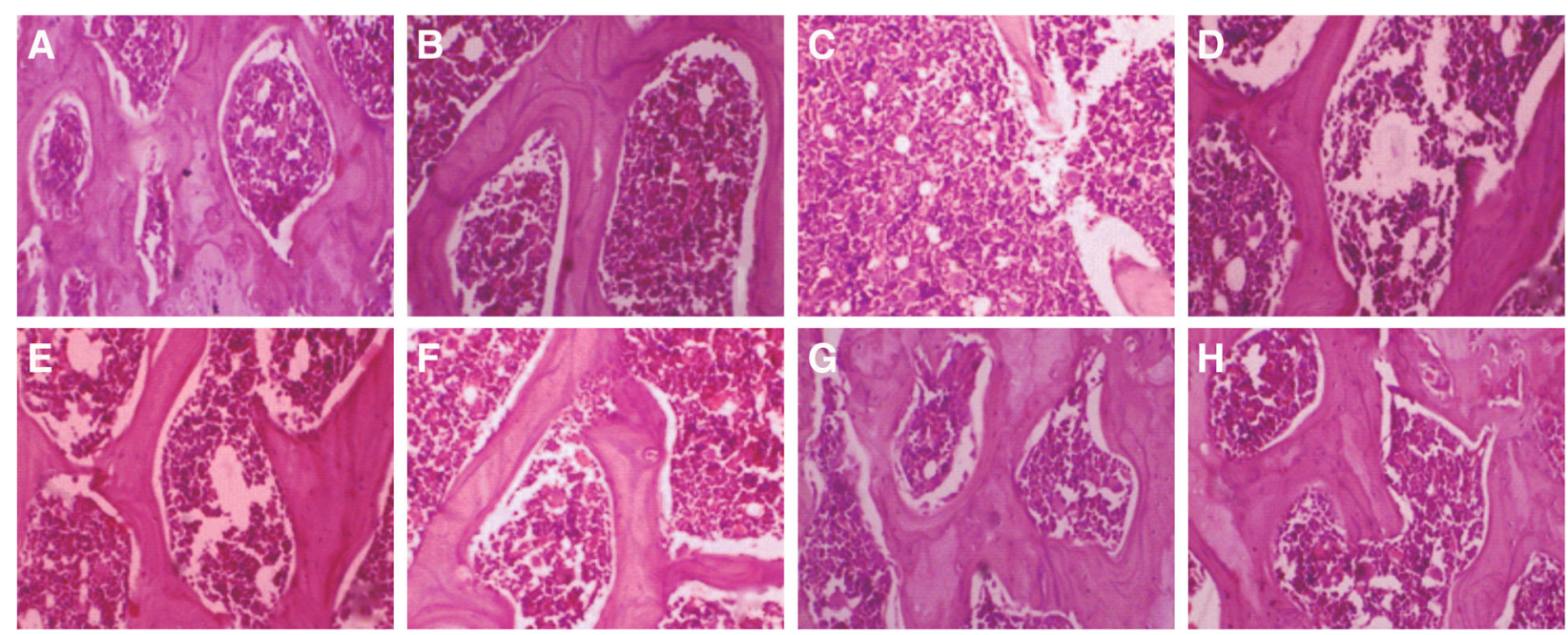

Fig. 7 Effect of plant extracts of B. ceiba on histopathological parameters of rat femur; $\mathbf{a}$ and $\mathbf{b}$ : NC and Sham, Longitudinal section of femur of normal control group and sham control showing compact, normal and uniform trabecular bone; c: OVX, OVX group showed widely separated and thin bone trabeculae, loss of interconnectivity and widening of bone marrow spaces; d and e: PE100 and PE200, Petroleum ether extract (100 and $200 \mathrm{mg} / \mathrm{kg}$ ) of B. ceiba showed less separated bone trabeculae, formation with reduced interconnectivity, narrowing of intertrabecular space; $\mathbf{f}$ and $\mathbf{g}$ :ME100 and ME200, Methanolic extract (100 and $200 \mathrm{mg} / \mathrm{kg}$ ) of B. ceiba showed compact, normal, thick and uniform bone trabeculae, interconnectivity between bone trabeculae, narrowing of bone marrow spaces; h: Std Ralox, Standard drug: Raloxifene (1 mg/kg) showed thickening of trabecular bone and restoration of normal architecture of bone (10X)

lumbar vertebra, and loading test of the femoral neck, reflecting marker for reduced bone strength, enhanced bone fragility and deterioration $[46,47]$.

In the histological study, petroleum ether and methanolic extract at 100 and $200 \mathrm{mg} / \mathrm{kg}$ each of B. ceiba significantly reversed the changes of bone fragility or bone loss, as compared to the OVX group. This restorative effect of $B$. ceiba extracts is significantly emphasized by increased interconnectivity between the bone trabeculae and reduced narrowing of bone marrow spaces in the femur bone when compared with OVX control. The integrity and compactness of bone were also significantly lost with thin trabeculae and narrow bone marrow spaces, in comparison to normal and sham-treated rats as also confirmed by histological observations.

Qualitative phytochemical screening of methanolic extract showed the presence of saponins, carbohydrates, flavonoids, tannins, steroids, and triterpenoids which may be responsible to ameliorate oxidative and inflammatory interventions in bone disorders. HPLC analysis of methanolic extract revealed the presence of Gallic acid for the first-time in the present study. Gallic acid, a phenolic acid is found to improve the bone strength and reduces bone loss by providing antioxidant action. It is reported to inhibit osteoclastogenesis induced by RANKL in RAW 264.7 cell lines in-vitro [59]. Gallic acid is found in nuts, fruits, leaves (tea) as polyphenol and associated with antioxidant and anti-inflammatory activities $[60,61]$. In another study at our laboratory, gallic acid has been lowered the surgically induced bone porosity and improved bone strength in female rats at 25 and $50 \mathrm{mg} / \mathrm{kg}$. Lupeol has been quantified in petroleum ether and methanolic extracts using HPTLC study and identified as a major contributor for the efficacy of B. ceiba for bone porosity and bone loss. Lupeol is reported to inhibit osteoclast differentiation and bone resorption through RANK, nuclear factor kappa-B (NF-kB), nuclear factor of activated T-cells (NFATC) and c-Fos (a proto-oncogene) in-vitro and in-vivo in an animal model of hypercalcemia mediated bone porosity [62]. A low dose combination of lupeol acetate and curcumin prevents activated osteoclast precursor associated diseases such as rheumatoid arthritis and osteoporosis [63]. Lupeol may play a significant role in improving bone remodeling and thus correcting bone loss via the FAS gene and TGF- $\beta$. B. ceiba is also reported to have anti-inflammatory and antioxidant effects and decreases NO production $[64,65]$. $\beta$-sitosterol, a phytosterol has been reported as an anti-inflammatory, angiogenic and hypocholesterolemic agent in in-vitro and in-vivo studies [66-68] and been quantified in the petroleum ether extract of the plant. In literature, B. ceiba is also documented to contain quercetin, a flavonoid which has been reported to lower loss of bone integrity cause due to ovariectomy in mice and restored bone repair [30, 31]. Flavonoid constituents are also identified qualitatively in B. ceiba methanolic extract under phytochemical screening which may have efficacy treating osteoporosis.

The efficacy of methanolic and petroleum ether extract was found to be similar in in-vitro and in-vivo studies. 
The presence of active constituents: beta-sitosterol (3.806\% in petroleum ether extract), lupeol (5.292\% petroleum ether extract and $3.812 \%$ in methanolic extract) and gallic acid $(3.616 \%$ in methanolic extract) may be correlated with the efficacy of B. ceiba stem bark along with some other constituents: flavonoids and tannins (as confirmed by qualitative phytochemical screening). This finding may further signify the use of intact plant part for the disease.

\section{Conclusion}

It may be concluded that B. ceiba: stem bark has pharmacological potential to ameliorate the condition of bone fragility and fracture due to the presence of phytoconstituents like containing lupeol, gallic acid and $\beta$-sitosterol. It can reverse the debilitating state of bone remodeling due to estrogenic modulation in-vitro and in-vivo and maintain calcium, phosphorus level, and bone integrity.

\section{Acknowledgments}

The authors are thankful to Shoolini University, Solan for providing research facilities.

\section{Funding}

The presented research does not involve any external research funding. The authors are thankful to Shoolini University, Solan for providing research facilities.

\section{Availability of data and materials}

The datasets used and/or analyzed during the current study are available from the corresponding author on reasonable request.

\section{Authors' contributions}

RG identified the problem and proposed the study. RG, AS, and SC, designed experimental protocol and carried out experimentation. NU, GS, and URL have designed experimental work related to phytochemical study including HPLC and HPTLC. RG and AS performed statistical analysis and interpreted research findings. SC and AS conducted experiments for in-vitro cell line study. All the authors read and approved the manuscript for publication.

\section{Ethics approval and consent to participate}

The presented research work involves the use of small experimental animals and the experimental protocol was duly approved from Institutional Animal Ethics Committee, Shoolini University, Solan, HP, India vide protocol no. IAEC/SU-PHARM/13/017, and was conducted as per the guidelines of Committee for the purpose of control and supervision of experiments on animals (CPCSEA) under Ministry of Environment, Forest \& Climate Change (under Prevention of Cruelty Act, 1960), Govt. of India, New Delhi, India. The study involves the use of small experimental animals which were procured from Animal house facility of the host institution, Shoolini University, Solan, $\mathrm{HP}$, India and the experiments adherence to a high standard (best practice) of veterinary care.

\section{Consent for publication}

Not applicable.

\section{Competing interests}

The author R. Goyal is a member of BMC CAM editorial board and other authors declares that they have no competing interests.

\section{Publisher's Note}

Springer Nature remains neutral with regard to jurisdictional claims in published maps and institutional affiliations.
Received: 28 April 2018 Accepted: 27 July 2018

Published online: 07 August 2018

\section{References}

1. Osteoporosis Prevention. Diagnosis, and therapy. NIH Consens Statement. 2000;17(1):1-36.

2. Raisz L. Pathogenesis of osteoporosis: concepts, conflicts, and prospects. J Clin Invest. 2005;12:3318-25.

3. Kanis JA. On behalf of the WHO scientific group. Assessment of osteoporosis at the primary health care level. Technical Report. WHO Collaborating Centre for Metabolic Bone Diseases, University of Sheffield, UK.2007.

4. Melton JL. How many women have osteoporosis now. J Bone Miner Res. 1995;10(2):175-7.

5. Osteoporosis Australia www.osteoporosis.tg.org.au/2004

6. Anderson DM, Maraskovsky E, Billingsley WL, Dougall WC, Tometsko $M E$, Roux ER, et al. A homologue of the TNF receptor and its legends enhance T-cell growth and dendritic-cell function. Nature. 1997;390: 175-9.

7. Lacey DL, Timms E, Tan HL, Kelley MJ, Dunstan CR, Burgess T, et al. Osteoprotegerin ligand is a cytokine that regulates osteoclast differentiation and activation. Cell. 1998;93(2):165-76.

8. Simonet WS, Lacey DL, Dunstan CR, Kelley M, Chang MS, Luthy R, et al. Osteoprotegerin: a novel secreted protein involved in the regulation of bone density. Cell. 1997;89(2):309-19.

9. Yasuda H, Shima N, Nakagawa N, Yamaguchi K, Kinoshaki M, Mochizuki $\mathrm{S}$, et al. (1988) Osteoclast differentiation factor is a ligand for osteoprotegerin/ osteoclastogenesis-inhibitory factor and is identical to TRANCE/RANKL. Proc. Natl. Acad. Sci. 1988;95:3597-602.

10. Zheng $R$, Lin S, Liu SY, Huang M, Gong W, Wu Z. Effect of estrogen on gene expression of fatty acid synthase in the periosteum. Chin Med J. 2009;122(15):1775-9.

11. Zheng SX, Vrindts Y, Lopez M, Groote DD, Zngerle PF, Collette J, et al. Increase in cytokine production (IL-1b, IL-6, TNF-a but not IFN-g, GM-CSF or LIF) by stimulated whole blood cells in postmenopausal osteoporosis. Maturitas. 1997;26(1):63-71.

12. Smith $\mathrm{S}$. The animal fatty acid synthase: one gene, one polypeptide, seven enzymes. FASEB J. 1999:8(15):1248-59.

13. Elbaz XW, Rivas D, Gimble JM, Duque G. Inhibition of fatty acid biosynthesis prevents adipocyte lipotoxicity on human osteoblasts in vitro. J Cell Mol Med. 2010;14(4):982-91.

14. Maurin AC, Chavassieux PM, Frappart L, Delmas PD, Serre CM. Influence of mature adipocytes on osteoblast proliferation in human primary cocultures. Bone. 2000;26(5):485-9.

15. Zhou S, Turgeman G, Harris SE, Leitman DC, Komm BS, Bodine PV. Estrogens activate bone morphoenetic protein-2 gene transcription in mouse mesenchymal stem cells. Mol Endocrinol. 2003;17(1):56-66.

16. Lane NE, Lukert B. The science, and therapy of glucocorticoid-induced bone loss. Endocrinol Metab Clin N Am. 1998;27(2):465-83.

17. Ji X, Chen D, Xu C, Harris SE, Mundy GR, et al. Patterns of gene expression associated with BMP-2-induced osteoblast and adipocyte differentiation of mesenchymal progenitor cell 3T3-F442A. J Bone Miner Metab. 2000;18(3):132-9.

18. Stanford CM, Jacobson PA, Eanes ED, Lembke LA, Midura RJ. Rapidly forming apatitic mineral in an osteoblastic cell line (UMR 106-01 BSP). J Biol Chem. 1995;270(16):9420-8.

19. Declercq H, Vreken NV, Maeyer ED, Verbeeck R, Schacht E, Ridder LD, Cornelissen M. Isolation, proliferation and differentiation of osteoblastic cells to study cell/biomaterial interactions: comparison of different isolation techniques and source. Biomaterials. 2004;25(5):757-68.

20. Brock J. Top end native plants - a comprehensive guide to the trees and shrubs of the top end of the Northern Territory, Australia, Reed New Holland, Darwin, Australia 2001

21. Aleem R, Ahmad SI, Ahmed M, Faizi Z, Rehman SZU, Ali M, et al. Hypotensive activity and toxicology of constituents from $B$. cieba stem bark. Biol Pharm Bull. 2003:26(1):41-6.

22. Joshi KR, Devkota HP, Yahara S, Simalin A, Simalin B. Two new aromatic compounds from the stem bark of Bombax ceiba. Phytochem Lett. 2014; $7(1): 26-9$.

23. Khan MF, Kumar M, Jaiswal N, Srivastava AK, Maurya R. a-Glucosidase inhibitor constituents from B. ceiba. Trends Carbohydr Res. 2010;2(4):29-34. 
24. Faizi S, Rehman SZU, Versiani MA. Shamiminol: a new aromatic glycoside from the stem bark of Bombax ceiba. Nat Prod Commun. 2011;6(12):897-900.

25. Verma V, Jalalpure SS, Sahu A, Bhardwaj LK, Prakash Y. Pharmacognostical, phytochemistry, ethnobotany, and pharmacology studies. Int Pharm Sci. 2011;1(2):62-8

26. Gupta P, Goyal R, Chauhan Y, Sharma PL. Possible modulation of FAS and PTP-1B signaling in the ameliorative potential of Bombax ceiba against highfat diet-induced obesity. BMC Comp Alt Med. 2013;13(281):281-91.

27. Jain V, Verma SK, Katewa SS. Myths, traditions and fate of multipurpose $B$. ceiba L. Indian J Trad Know. 2009;8:638-44.

28. Jain V, Verma SK. Assessment of credibility of some folk medicinal claims on B. ceiba L. Indian J Trad Know. 2014;13(1):87-94.

29. Verma G, Gupta R, Gupta SP. Development of HPTLC densitometric method for estimation of quercetin in Bombax ceiba L. leaves. J Adv Res. 2014;5(2):50-2.

30. Tsuji M, Yamamoto H, Sato T, Mizuha Y, Kawai Y, Taketani Y, Kato S, Terao J, Inakuma T, Takeda E. Dietary quercetin inhibits bone loss without effect on the uterus in ovariectomized mice. J Bone Min Met. 2009;27(6):673-81.

31. Forte L, Torricelli P, Boanini E, Gazzano M, Rubini K, Fini M, Bigi A. Antioxidant and bone repair properties of quercetin-functionalized hydroxyapatite: an in vitro osteoblast-osteoclast-endothelial cell co-culture study. Acta Biomater. 2016;1(32):298-308.

32. Sharma A, Goyal R, Sharma L. Potential biological efficacy of Pinus plant species against oxidative, inflammatory and microbial disorders. BMC Complement Altern Med. 2016;16(35):1-11.

33. Tewari P, Kumar B, Kaur M, Kaur G, Kaur H. Phytochemical screening and extraction: a review. Internationale Pharmaceutica Sciencia. 2011:1:98-106.

34. Lal UR, Tripathi SM, Jachak SM, Bhutani KK, Singh IP. HPLC analysis and standardization of Arjunarishta-an Ayurvedic Cardioprotective formulation. Sci Pharm. 2009;77:605-16.

35. Sethi PD. HPTLC, CBS publishers and distributors 1st edition New Delhi 1996.

36. Xiong Z, Wang D, Xu Y, Li F. Osteoblastic differentiation bioassay and its application to investigating the activity of fractions and compounds from Psoralea corylifolia. Pharmazie. 2003;58(12):925-8.

37. Wang D, Li F, Jiang Z. Osteoblastic proliferation stimulating activity of Psoralea corylifolia extracts and two of its flavonoids. Planta Med. 2001;67: 748-9.

38. Cortizo AM, Sedlinsky C, McCarthy AD, Blanco A, Schurman L. Osteogenic actions of the anti-diabetic drug metformin on osteoblasts in culture. Eur J Pharmacol. 2006;536(1-2):38-46.

39. Gupta R, Goyal R, Bhattacharya S, Dhar KL. Antioxidative in vitro and antiosteoporotic activities of Prinsepia utilis Royle in female rats. Eur J Integ Med. 2014;7(2):157-63.

40. Lasota A, Danowska KD. Experimental osteoporosis- different methods of ovariectomy in female white rats. Rocz Akad Med Bialymst. 2004;49(1):129-31.

41. Kadaba R, Simpson CW. Disparate effect of Raloxifene in rats with experimentally induced endometriosis. Endocrinology. 1990;126(6):3263-7.

42. Folwarczna J, Sliwiński L, Cegieła U, Pytlik M, Kaczmarczyk-Sedlak I, Nowińska B, Janiec W, Trzeciak HI. Raloxifene similarly affects the skeletal system of male and ovariectomized female rats. Pharmacol Rep. 2007;59(3): 349-58

43. Michael JK, Maren H, Karen LJ, James PD, James CK, Louis EM, Richard TT, Kelly DH. (1997) comparison of bone density measurement techniques: DXA and Archimedes principle. J Bone Miner Res. 1997;12(11):1903-7.

44. Wang J, Chen CC, Saki S. Optimization of the phosphorus UV reagent. Clin Chem. 1983:29:1255.

45. Ke B, Xu Z, Ling Y, Qiu W, Xu Y, Higa T. Aruoma Ol modulation of experimental osteoporosis in rats by the antioxidant beverage effective microorganism-X (EM-X). Biomed Pharmaco. 2009;63(2):114-9.

46. Peng Z, Tuukkanen J, Zhang $H$. The mechanical strength of bone in different rat models of experimental osteoporosis. Bone. 1994;15(5):523-32.

47. Ogey BF, Sevin GA. Comparative study of Raloxifene and estrogen on bone strength and cholesterol levels in ovariectomized rats. Endo Abstr. 2001:3:10.

48. Meczekalski B, Czyzyk A. Selective estrogen receptor modulators in the treatment of postmenopausal osteoporosis. Ginekol Pol. 2009:80(3):213-7.

49. Kimmel DB Animal models for in vivo experimentation in osteoporosis research. In Osteoporosis. Academic Press: San Diego, CA, USA 1996.

50. Ljunghall S, Johansson AG, Burman P, Kämpe O, Lindh E, Karlsson FA. Low plasma levels of insulin-like growth factor I (IGF-I) in male patients with idiopathic osteoporosis. J Intern Med. 1992;232(1):59-64.
51. Cole Z, Dennison E. Cooper C update on the treatment of post-menopausal osteoporosis. Br Med Bull. 2008;86:129-43.

52. Aswar UM, Mohan V, Bodhankar SL. The antiosteoporotic activity of phytoestrogen-rich fraction separated from the ethanol extract of aerial parts of Cissus quadrangularis in ovariectomized rats. Ind J Pharmacol. 2012; 44(3):345-50.

53. Jee WSS, Yao W. Overview: animal models of osteopenia and osteoporosis. J Musculoskelet Neuronal Interact. 2001;1(3):193-207.

54. Watts NB. Clinical utility of biochemical markers of bone remodeling. Clin Chem. 1999;45:1359-68.

55. Shirwaikar A, Setty M, Bommu P. Effect of Lupeol isolated from Cratae vanurvala Buch-ham. Stem bark extract against free radical-induced nephrotoxicity in rats. Indian J Exp Biol. 2004;42(7):686-90.

56. Bonjour JP. Calcium and phosphate: a duet of ions playing for bone health. J Am Coll Nutr. 2011:30(5):438S-48S.

57. Mo XM, Zeng Y, Hong J. Biochemical characteristics of an ovariectomized female rat model of osteoporosis. J Tradit Complement Med. 1999:526-8.

58. Sipos W, Pietschmann P, Rauner M, Kerschan-Schindl K, Patsch J. (2009) pathophysiology of osteoporosis. Wien Med Wochenschr. 2009;159(910):230-4.

59. Lin RW, Ho ML, Wang YH, Chen IS, Wan GJ. Green Tea Polyphenols inhibit Osteoclastic Differentiation. 55th Annual Meeting of the Orthopaedic Research Society, Las Vegas, USA.2009.

60. Franziska F, Asima C, Tatjana S, Michael K, Siegfried K. Antioxidant and free radical scavenging activities of sumac (Rhuscoriaria) and identification of Gallic acid as its active principle. BMC Pharmacol. 2007:7(2):A71.

61. Kroes BH, Berg AJV, Ufford HCQ, Labadie RP. Anti-inflammatory activity of Gallic acid. Planta Med. 1992:58(6):499-504.

62. Im NK, Lee DS, Lee SR, Jeong GS. Lupeol isolated from Sorbus commixta suppresses 1a,25-(OH)2D3-mediated osteoclast differentiation and bone loss in vitro and in vivo. J Nat Prod. 2016;79(2):412-20.

63. Hwang JJ, Wang WH. Combination of Lupeol acetate and curcumin used for the treatment or prevention of activated osteoclast precursor associated disorders. US20160220582 A1; 2016

64. Dar A, Faizi S, Naqvi S, Roome T, Zikr-ur-Rehman S, Ali M, Firdous S, Moin ST. Analgesic and antioxidant activity of mangiferin and its derivatives: the structure-activity relationship. Biol Pharm Bull. 2005:28(4):596-600.

65. Hossain E, Sarkar D, Chatterjee M, Chakraborty S, Mandal SC. Gupta JK (2013) effect of methanol extract of Bombax malabericum leaves on nitric oxide production during inflammation. Acta Pol Pharm. 2013;70(2):255-60.

66. Prieto JM, Recio MC, Giner RM. Anti-inflammatory activity of $\beta$-sitosterol in a model of oxazolone induced contact-delayed-type hypersensitivity. Bol Latinoam Caribe Plant Med Aromat. 2006;5:57-62.

67. Zak A, Zeman M, Vitkova D, Hrabak P, Tvrzicka E. Beta-sitosterol in the treatment of hypercholesterolemia. Cas Lek Cesk. 1990;129:1320-3.

68. Moon EJ, Lee YM, Lee $\mathrm{OH}$, Lee MJ, Lee SK, Chung MH, et al. A novel angiogenic factor derived ffrom Aloe vera gel: beta-sitosterol, a plant sterol. Angiogenesis. 1999:3:117-23.

Ready to submit your research? Choose BMC and benefit from:

- fast, convenient online submission

- thorough peer review by experienced researchers in your field

- rapid publication on acceptance

- support for research data, including large and complex data types

- gold Open Access which fosters wider collaboration and increased citations

- maximum visibility for your research: over $100 \mathrm{M}$ website views per year

At BMC, research is always in progress.

Learn more biomedcentral.com/submission 